\title{
Creativity and the resilient health librarian
}

\author{
Shelley Hourston
}

Amanda Credaro [1] writes, "Librarians are people too! I don't know about you, buddy, but I'm no beige mouse!" Librarian stereotypes have fuelled coffee break and pub night conversations for librarians for generations. Implicit in the stereotype is the notion that librarians are just about as uncreative as anyone could be. I have surveyed librarians from around the world, most recently health librarians, and I am pleased to report that quite the opposite is true.

For the past couple of years I have been on a quest to discover the secret to resilience for librarians. People have shared stories that were inspiring, breathtaking, humbling, heart wrenching, and heartwarming. I was intrigued to discover that creativity - from artistic expression to creative thinking — was a common thread throughout.

That creativity is a theme in resilience is hardly surprising. Indeed, resilience, often defined as buoyancy or an ability to adapt and bounce back from adversity, trauma, or personal and workplace stress, requires renewal and the ability to perceive or generate new options. Curious about whether creativity is a personality trait or a skill that can be learned, I polled librarians on the topic. I talked to 23 librarians (20 of them work in health libraries) from Canada, the US, England, Scotland, Austria, Sweden, and Australia. Based on my research and feedback from colleagues, I believe that librarianship is a profession that demands creativity. Many people define creativity as either artistic or applied (creative thinking skills). During the course of my research, it has become clear that creative expression is a continuum. Interestingly, it is not necessary to believe that you are creative to be creative. However, consciously using creativity can generate a greater number of options and more creative results. Perhaps more important is that by recognizing and nurturing creativity in ourselves - whether expressed through artistic endeavours or through creative thinking techniques — we can improve our resilience.

\section{The creative core of resilience}

Psychiatrist and author Frederic Flach describes in Resilience: Discovering a New Strength at Times of Stress what he calls "the law of disruption and reintegration". Flach's theory is that what has traditionally been categorized as mental illness (from chronic depression to chronic anxiety disorder or chronic

S. Hourston. S. Hourston \& Associates, 101-1857 West 4th Avenue, Vancouver, BC V6J 1M4, Canada (e-mail: shelley@shourstonandassociates.com, Web site: http://www.shourstonandassociates.com). post-traumatic stress disorder) is a normal reaction to adversity or trauma. He contends that "real illness" is "being unable to fall apart and reintegrate afterwards" [2].

Flach has developed a profile of the resilient personality. Inner strengths include a strong self-esteem, a sense of responsibility and personal discipline, recognition and development of gifts and talents, creativity evidenced by openness to new ideas and a "willingness to dream", a wide range of interests, a sense of humour, a moderate tolerance for distress, focus, commitment to life, and faith - a philosophical or spiritual framework from which to operate [3]. The interpersonal strengths of resilient people, as described by Flach, include "independence of thought and action", ability to compromise, a strong network of family and friends, ability to let go and forgive oneself and others, ability to set limits, ability to protect against selfishness, generosity, and the ability to give and receive love [4].

Of particular interest, however, is Flach's view that creativity is essential to resilience. Resilience is part of what he calls a "bifurcation point" that involves a shift from a homeostasis or what we consider to be normalcy to disruption to chaos to resilience to reintegration and finally to a new homeostatic structure. Examples of bifurcation points include life changes such as adolescence or middle age, as well as job loss, loss of a partner or child, etc. During "bifurcation point stress", Flach says that "things are a shambles" and the future is uncertain. In addition, once we come through the process to reintegration, we must learn to adapt to "new and unfamiliar homeostases". He argues that the tool required to traverse bifurcation point stress is creativity: "The creative act does not create something out of nothing. It rearranges, combines, and synthesizes already existing facts, ideas, and frames of reference. Most agree that it does not follow the rules of ordinary logic; instead, it is rooted in an irrational way of thinking, with emotional and intellectual forces beyond consciousness playing vital roles" [5]. Flach adds, "In its broadest sense, creativity can be defined as a response to a situation that calls for a novel but adaptive solution, one that serves to accomplish a goal" [6]. Creativity requires unlearning previous strategies and approaches and utilizing the unconscious mind. Flach points out that many are misled by the belief that creativity involves a talent expressed through artistic endeavours or resulting in scientific discoveries rather than an approach to everyday living.

\section{Librarianship: a profession built on creativity}

Flach's description of the creative act as rearranging, com- 
bining, and synthesizing already existing facts, ideas, and frames of reference reminded me of some of the elements of our work: cataloguing (classification, subject indexing); reference interviews; collection development; database searching; justifying the existence of the library; to mention a few. Our work requires that we identify links between pieces of information and utilize knowledge and resources to get to additional information. We navigate a sea of information using our insight into patterns, connections, and relationships. Although not every client is dealing with Flach's bifurcation point stress, librarians have the skills to help library users travel from one homeostatic structure to another. Subject analysis, synthesis, and extrapolation demand an understanding of information and knowledge — often from unfamiliar disciplines, under a deadline, and on the fly — unparalleled in many other professions.

Julie Renee Moore, catalogue librarian at California State University in Fresno, says, "I think applied creativity is basically what I get paid for. If I weren't coming up with new ideas and solutions, then I would not be doing my job, as I define it." She believes that "librarianship lends itself to creativity, because something is always changing!" Unlike other librarians who have indicated that cataloguing may be one of the areas of librarianship where creativity is least possible, Moore says that "cataloguing in particular, lends itself to creativity. There are the Rules and Rule Interpretations ... but then how do you apply the rules to this oddball thing that is on your desk. I just recently had a goat-hoof rattle placed on my desk to be catalogued."

Tricia Rey, library services manager with Queen Victoria Hospital NHS Foundation Trust in England, notes that "health librarians are often at the forefront of new developments and may find creativity essential to overcome problems which arise with the implementation of new systems.... [They also] may work in small units with little or no close contact with colleagues and therefore have to rely heavily upon their own creativity to achieve."

Librarian Marylaine Block wrote in Ex Libris: an E-Zine for Librarians and Other Information Junkies, "I've just been reading a fascinating book called Sparks of Genius: the 13 Thinking Tools of the World's Most Creative People (Boston: Houghton Mifflin, 1999), and couldn't help noticing that librarians use virtually all of those tools routinely in the course of their normal workday" [7]. She points out that techniques such as observation, abstraction, modeling, recognizing and forming patterns, empathy, synthesis, and transformation are common to various aspects of librarianship. While not commonly recognized as such, play is also a creative approach used by librarians: "Even when we've found exactly what our user wanted, many of us will keep on looking, keep on playing because we became more curious about the topic than our user did.... Knowledge is a lot like a ball of yarn" [8]. Whether or not we acknowledge our creativity, it is clear that librarians are professional creative thinkers.

\section{Consciously or unconsciously creative}

Some, as Flach notes, believe creativity to be limited to artistic expression. It is sometimes thought that the greater the recognition or financial reward for artistic efforts, the higher the level of creativity. The perception of creativity as artistic or applied is a result of focusing on the ultimate manifestation of creative energy such as a painting or a creative solution to budget cuts for the library. It is clear from the librarians I consulted that creative energy exists and is a positive force, whether it manifests as art or craft work or creative programming and problem solving in the workplace. A health librarian in Sweden believes that if you are creative, you are generally creative in both the artistic and the applied sense.

In reference to artistic creativity, one health librarian from Australia told me that she did not have "a creative bone" in her body. However, she attributed her success during 23 years as a manager in special libraries to her applied creativity. She uses brainstorming extensively, capitalizing on the additional benefit of staff empowerment when they see their ideas implemented. She added, "Creativity also covers being political, being able to choose and cultivate champions, being able to see not just the black and white but also the shades of grey when it comes to customer service." Sarah Sutton, a librarian at the Clinical Sciences Library, University of Leicester, also described her creative thinking techniques as intentional. She grew up with a family "tradition of trying many methods ... I do like to try and come at problems from lots of angles ... if I come up against a wall I try and think of lots of ways round it rather than taking the wall as an immovable obstruction ... a bit like a mouse in a maze."

Whether or not we are conscious of our creative energy or agree on definitions of creativity, it is clear that we have and use creative energy in our work as librarians. If creativity is a key characteristic of resilience then librarians are in a very strong position to cope with the inevitable challenges we all face. Perhaps it means that we have an inherent aptitude for bouncing back from the personal and professional hurdles that appear over a lifetime.

\section{Benefits of creativity}

Many librarians not only recognize the creative aspects of their work but recommend pursuing or nurturing creativity. Graham Walton at Loughborough University Library in the UK has been actively working to apply creativity principles in libraries for some time. He is co-editor of Exploiting Information in Health Services and author of a chapter within called "Developing Innovative Services and Managing Change". He writes, "For creativity to flourish requires a climate conducive to creative thinking.... A librarian has to become sensitive to, and aware of, external events as well as recognizing patterns and trends in their working environment. This allows intuition to become very effective in creatively developing services." He also notes that the "small size of many health libraries provides an inherent advantage for innovation" [9].

Regarding artistic creativity, a health librarian in Sweden says, "It gives meaning to life. Artistic creativity makes my life easier. It's therapy. It makes me strong. It makes me a better person." He believes that it is "very important to foster creativity".

Sharon Hadley, a librarian with the National Library for Health in the UK, says, "Fostering creativity not only supports personal resilience but the ability to think out of the 
box can support us professionally, e.g., thinking of costeffective solutions to a problem.... [W] craft activities in my personal life increases my resilience and allows me to relax. Knitting really is as good as yoga!"

Joy Huebert, library director at Trail \& District Public Library in British Columbia, is passionate about her artistic endeavours: "I am a member of a writing group and I also explore visual art through painting and drawing. I have often felt that my creative life is the most essential and best part of myself, and a source of insight and strength. Writing a story or painting with beautiful colours connects me to a source of truth, joy and light that gives me strength to deal with the stresses and conflicts in public service work." A health librarian in Scotland says, "Creativity is essential to me. Without means of creative expression, my mental health would suffer... My writing and art and craft work offer me a means of expression for my emotions, allowing me to sort out my problems and to find solutions. It also builds my self esteem, giving me confidence."

Mary Doug Wright, a consulting health librarian with Apex Information in Vancouver, B.C., says that artistic expression enables her to focus and "brings energy to other parts of my life that's not there when I don't do my art. Having a creative outlet allows me to do my work better. Firing those creative cells in my brain helps me be more creative in my research. I bring that spark to approaching my research question from a creative point of view ... to answer those questions the best way I can."

Julie Renee Moore notes that "the artistic side of me (doing photography, painting, drawing, etc.) provides the energy to propel my resilience. It is almost like the nutrition for my resilience. My artistic side makes my life much fuller and more satisfying." Linda Howard, librarian with Fraser Health Library Services in British Columbia, applies "different thinking to come up with novel solutions to problems or challenges. Creativity in everyday life is important to me and I think it adds a dimension to work life that refreshes the soul."

\section{The flickering flame of creative energy}

As abundant as creative energy is among librarians, it should never be taken for granted. Several librarians mentioned the negative impact that poor work environments and low energy can have on creativity. A health librarian in the UK described feeling "less and less resilient to the problems I was encountering in my work. The organization was in dire straits ... [and] there was a general air of apathy and cynicism within the organization. I stopped all my sewing and my enthusiasm to plan my life disappeared. I felt my creativity to solve problems, move on, and look forward was being killed by the apathy around me." She ultimately resigned, found a new position in a more positive environment, and felt her enthusiasm for sewing, art, and reading return: "I feel more resilient to whatever life can throw at me."

Paola Durando, public services librarian at Bracken Health Sciences Library at Queens University in Kingston, Ont., is a quilter and maintains a blog called Quilting Librarian (http://www.quiltinglibrarian.blogspot.com/). She describes her creative energy as drying up "when my job responsibilities and parenting have sapped all my energy. The last thing
I want to do is sew. When I do force myself to go into my sewing room and shut the door, the creativity inevitably takes over. Skin touches fabric, colour goes next to colour, and I make something warm and beautiful. My heart slows down, and nagging thoughts effortlessly turn into either acceptance or solutions."

\section{How can we nurture creative energy?}

Acknowledging and nurturing our creativity is a way of building our resilience. By understanding that we are creative and that creativity is key to resilience, we can be more confident and competent when facing a bifurcation point. If you are not currently capitalizing on the benefits of artistic expression to nurture your creative energy, you may want to consider exploring a new hobby. For example, a senior information professional with the National Blood Service in England is a published poet who has recently been invited to publish her work in the US. A US-based academic librarian and former health librarian uses his creative energy as a trained musician and as a gardener.

Julie Renee Moore's artistic expression covers a wide range. She draws, paints, and enjoys photography. She points out the importance of the creative experience, which may or may not result in works of art: "My son is both very tactile and creative ... we often spend a lot of time playing with Play-Doh, Silly-Putty, or just running our hands through a bowl of birdseeds."

Other artistic ventures described by the librarians I surveyed included writing, painting, drawing, sculpture, crafts, knitting, and Paola Durando's blog for fellow librarian quilters with the tag line "we need a high-touch antidote to our hightech occupations". Ana Rosa Blue, a librarian with Vancouver Coastal Health Library Services, has several artistic outlets including knitting, Chinese knotting, baking, and making her own greeting cards.

Musician, writer, and librarian Paul T. Jackson of Trescott Research in Enumclaw, Wash., sums it up succinctly when he says librarians "are resilient because we have to be. Creativity is one of the tools that helps us."

\section{References}

1. Credaro A. Rejecting the stereotype. Warrior Librar Wkly [serial on the Internet]. [updated 2006 Jan 29; cited 2006 Mar 28]. Available from http://www.warriorlibrarian.com/IMHO/stereo.html.

2. Flach F. Resilience: discovering a new strength at times of stress. New York: Hatherleigh Press; 2004. p. 20.

3. Ibid., p. 105.

4. Ibid., p. 105-6.

5. Ibid., p. 146.

6. Ibid., p. 147.

7. Block M. Librarianship and creativity. Ex Libris: an e-zine for librarians and other information junkies [serial on the Internet]. 2001 Jun 29 [cited 2006 Mar 28];104. Available from http://marylaine.com/exlibris/xlib104.html.

8. Ibid.

9. Walton G. Developing innovative services and managing change. In: Walton G, Booth A, editors. Exploiting information in health services. London: Facet Publishing; 2004. p. 137-46. 